J. Clin. Chem. Clin. Biochem.

Vol. 17, 1979, pp. $777-780$

\title{
Effect of Cadmium and Copper on Monoamine Oxidase Type A and B in Brain and Liver
Mitochondria
}

\author{
By S. Magour, Olga Cumpelik and Murgarete Paulus \\ Gesellschaft für Strahlen- und Umweltforschung, Department of Toxicology, Neuherberg, W. Germany
}

(Received December 30, 1978/June 25, 1979)

Summary: The effect of cadmium and copper on monoamine oxidase type A and B in mitochondrial preparations from brain and liver was determined in vitro. The results showed a dose-related inhibition of the enzyme. Both the $A$ and $B$ forms of the enzyme were similarly inhibited by the presence of either cadmium or copper. Copper has been shown to be a 7-8 times more potent inhibitor of monoamine oxidase than cadmium. The data suggest that the intracellular concentration of unbound copper $(13 \mu \mathrm{mol} / \mathrm{l})$ or cadmium $(100 \mu \mathrm{mol} / \mathrm{l})$ may inhibit monoamine oxidase in brain and liver by $50 \%$.

\section{Der Einfluß von Cadmium und Kupfer auf die Monoaminoxidase $A$ und $B$ in Gehirn- und Lebermitochondrien}

Zusammenfassung: Der Einfluß von Cadmium und Kupfer auf die mitochondriale Monoaminoxidase A und B wurde in vitro untersucht. Die Ergebnisse zeigten eine dosis-abhängige Hemmung des Enzyms. Die beiden Formen A und B des Enzyms wurden in Gegenwart von Cadmium oder Kupfer jeweils in gleicher Weise gehemmt. Die Hemmung durch Kupfer war 7-8 mal stärker als die von Cadmium.

Die Ergebnisse deuten daraufhin, daß eine intrazelluläre Konzentration von nicht gebundenem Kupfer (13 $\mu \mathrm{mol} / \mathrm{l})$ oder Cadmium ( $100 \mu \mathrm{mol} / \mathrm{l})$ die Monoaminoxidase in Gehirn und Leber um 50\% hemmen können.

\section{Introduction}

Monamine oxidase (E.C. 1.4.3.4) is a major enzyme in the catabolism of the putative transmitter monoamines and is widely distributed in human tissues. Any change in the enzyme activity may alter the neurotransmitter functions. Recently it has been suggested that monoamine oxidase, at least in brain and liver, exists in multiple forms, type A and type B $(1,2)$. The A form of the enzyme which selectively deaminates 5 -hydroxytryptamine and norepinephrine, is inhibited by chlorgyline. The B form of monoamine oxidase, which selectively degrades benzylamine and $\beta$-phenylethylamine, is inhibited by deprenyl. Tyramine and dopamine are commion sub: strates for both types of the enzyme (3).

It has also been shown that monoamine oxidase contains functionally important sulfhydryl groups $(-\mathrm{SH})$ and can be inhibited non-competitively by certain sulfhydryl reagents and heavy metals (4-7). It is also known that some heavy metals are powerful inhibitors of other $-\mathrm{SH}$ containing enzymes (8). The human body is becoming increasingly contaminated with cadmium and copper, which have been introduced into the environment as a consequence of the rapid expansion in industrial technology. Moreover, cadmium is thought to be one of the most hazardous environmental contaminants and has been the subject of many studies related to its effects on human health (9). Because of the central role of monoamine oxidase in biogenic amine metabolism in central and peripheral nervous systems, it was thought important to determine the effect of cadmium and copper on this enzyme in the brain and liver of rats. This study should also give some information on the inhibition characteristics of both forms of monoamine oxidase in the presence of these heavy metals. 


\section{Materials and Methods}

5 -hydroxy tryptamine creatinine sulfate, $\beta$-phenylethylamine $\mathrm{HCl}$ and bovine plasma monoamine oxidase were purchased from Sigma Chemical Co., U.S.A., $\left[{ }^{14} \mathrm{C}\right] 5$-hydroxytryptamine creatinine sulfate (spec. act. $2.15 \mathrm{TBq} / \mathrm{mol}$ ) from Amersham Buchler Co., Germany, and $\left[{ }^{14} \mathrm{C}\right.$ ) phenylethylamine hydrochloride (spec. act. 1.79 TBq/mol) from New England Nuclear, U.S.A. Cadmium chloride, copper sulfate and all other chemicals were purchased from Merck AG, Germany, and were of analytical grade.

Male Wistar rats (180-200 g) were killed by decapitation. From each animal the brain and liver were immediately excised, weighed and immersed in ice cold $9 \mathrm{~g} / 1$ saline to remove the adhering blood. These tissues were homogenized in chilled $0.25 \mathrm{~mol} / 1$ sucrose (adjusted to $\mathrm{pH} 7.0$ with Tris/ $\mathrm{HCl}$ ) to give a $10 \%$ suspension using a glass-Teflon homogenizer. The homogenate was centrifuged for 10 minutes at $1000 \mathrm{~g}$, the pellet was discarded, and the supernatant was centrifuged at $15,000 \mathrm{~g}$ max. for 20 minutes. The pellet (mitochondria) was rehomogenized in $50 \mathrm{mmol} / 1 \mathrm{Tris} / \mathrm{HCl}$ buffer $\mathrm{pH} 7.4$ to give a $10 \%$ suspension, which was used for the assay.

\section{Assay of monoamine oxidase activity}

Enzyme activity was measured by a modified method based on that described previously (10). The assay mixture contained in a final volume of $0.5 \mathrm{ml}: 100 \mu \mathrm{l}$ of the mitochondrial preparation, $1 \mathrm{mmol} / 15$-hydroxy tryptamine or $\beta$-phenyle thylamine and $50 \mathrm{mmol} / 1 \mathrm{Tris} / \mathrm{HCl}$ buffer $\mathrm{pH} 7.4$. The concentrations of 5-hydroxy tryptamine and phenylethylamine used in this study were $1 \mathrm{mmol} / \mathrm{l}$; this concentration ensures saturation of the enzyme without causing substrate inhibition, as shown in pilot experiments.

The samples were preincubated without substrate for 10 minutes at $37^{\circ} \mathrm{C}$ in the presence or absence of cadmium or copper salts (final concentration range: $1-1000 \mu \mathrm{mol} / 1$ ). After addition of the substrate, the incubation mixtures were further incubated for another 30 minutes, and the reaction was stopped by the addition of $100 \mu \mathrm{l}$ of $6 \mathrm{~mol} / \mathrm{l}$ $\mathrm{HCl}$. The deaminated products were extracted as follows: metabolites of 5-hydroxy tryptamine extracted into $2 \mathrm{ml}$ ethyl acetate/benzene (volumes, $1 \mathrm{ml}+1 \mathrm{ml}$ ), and those of phenylethylamine into $2 \mathrm{ml}$ heptane. After centrifugation, $1 \mathrm{ml}$ of the organic phase was added to $10 \mathrm{ml}$ of toluenebased scintillant and counted in a Searle Mark III liquid scintillation spectrometer equipped with a DPM device.

Blanks including substrates were run with each determination. and were prepared by adding $\mathrm{HCl}$ to the non-incubated assay. Protein content was assayed according to Lowry et al. (11) using bovine serum albumin as a standard. Monoamine oxidase activity was determined as DPM of the aldehyde formed $/ \mathrm{mg}$ protein - 30 minutes and was used to calculate the relative enzyme activity remaining after the addition of $\mathrm{Cd}^{++}$or $\mathrm{Cu}^{++}$.

\section{Difference spectra determination}

The interaction of $\mathrm{Cu}^{++}$and $\mathrm{Cd}^{++}$with $\beta$-phenylethylamine and monoamine oxidase was determined by measuring the difference spectra of the individual substances using a Zeissspectrophotometer DMQ 21. All substances were dissolved in deionized water and the $\mathrm{pH}$ values of 7.4 were maintained with $\mathrm{NaOH}$ instead of buffer solutions to avoid any possible interaction between the buffer components and the heavy metals.

\section{Results and Discussion}

The data in figure 1 show that increasing concentrations of $\mathrm{Cd}^{++}$resulted in a simple sigmoid inhibition curve for the brain and liver monoamine oxidase when $1 \mathrm{mmol} / 15$ -
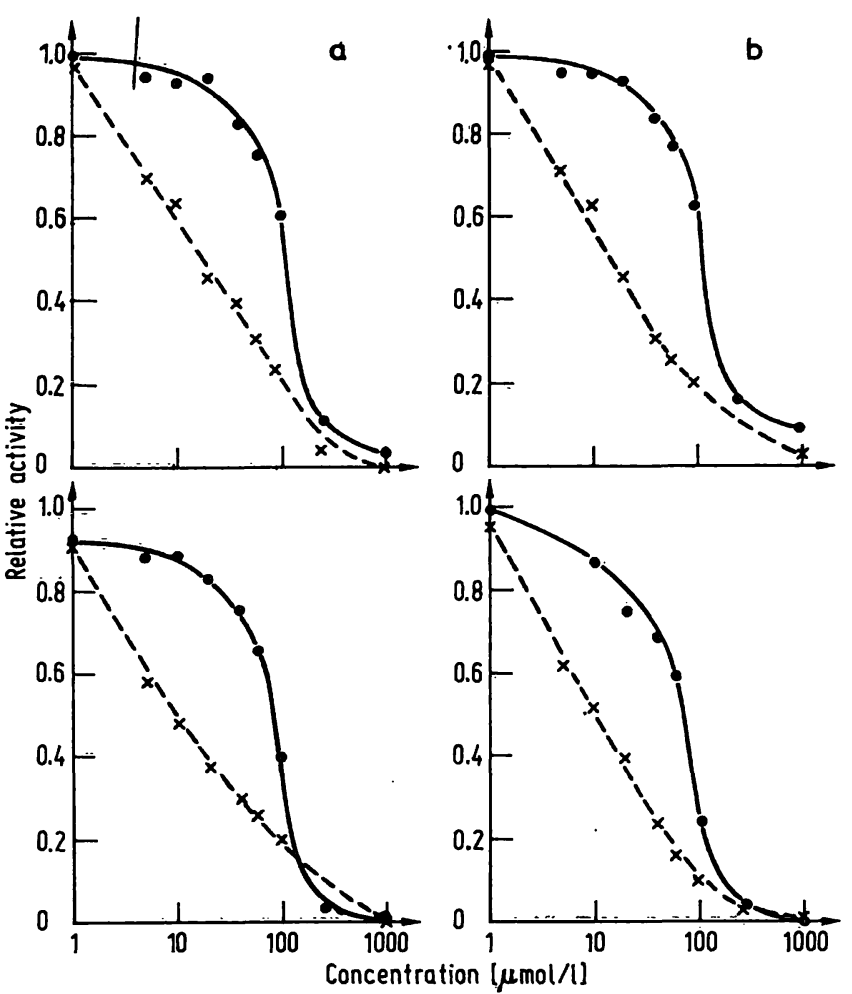

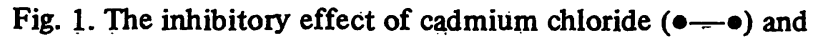
copper sulfate $(x-x)$ on 5-hydroxy tryptamine (a) and $\beta$-phenylethylamine (b) deamination in rat brain (top) and liver (bottom) mitochondria. Each point is the average of 6-9 rats. Experimental details are described in Methods.

hydroxytryptamine or $\beta$-phenylethylamine were used as substrates. This type of inhibition is compatible with sulfhydryl group involvement in $\mathrm{Cd}^{++}$inhibition of monoamine oxidase rather than a non-specific denaturation of the enzyme (12).

It is also evident that both types A and B of monoamine oxidase are similarly inhibited by either cadmium or copper, which suggests that the protein moieties in both types are very similar. Houslay \& Tipton (14) showed that removal of lipids from monoamine oxidase resulted in only a single band of enzyme activity on subsequent electrophoresis. The data also show that the deamination of 5-hydroxytryptamine and $\beta$-phenylethylamine could be almost completely inhibited by $0.2 \mathrm{mmol} / 1$ of either cadmium chloride or copper sulfate. These findings are in contrast with those of Revis \& Horton (13) who observed very low and nonsignificant inhibition of monoamine oxidase in brain and liver of rats in the presence of $1 \mathrm{mmol} / 1 \mathrm{cadmium}$ or copper. This apparent discrepancy is probably due to differences in the buffer systems used: In the present study we used $50 \mathrm{mmol} / \mathrm{l}$ Tris/HCl buffer while Revis \& Horton used $240 \mathrm{mmol} / 1$ potassium phosphate buffer. It is likely that $\mathrm{Cd}^{++}$and $\mathrm{Cu}^{++}$may have reacted chemically with the phosphate groups of the buffer used by Revis \& Horton thus

forming water-insoluble phosphate complexes which may not have reacted with the sulfhydryl or other functionally important ligands of the enzyme. 
It is also evident that $\mathrm{Cd}^{++}$was a relatively weaker inhibitor of the deamination of both 5-hydroxytryptamine and $\beta$-phenylethylamine than $\mathrm{Cu}^{++}$. Low concentrations of $\mathrm{Cu}^{++}$(up to $5 \mu \mathrm{mol} / \mathrm{l}$ ) produced about $30 \%$ inhibition of 5-hydroxytryptamine and $\beta$-phenylethylamine deamination, while $\mathrm{Cd}^{++}$was almost without effect.

It is possible that copper (but not cadmium) may have interacted with the substrates used in our study, thus preventing the oxidative deamination by the enzyme. Due to the high chemical reactivity of $\mathrm{Cu}^{++}$this metal ion may also react with a greater number of enzymic ligands as compared to cadmium.

In order to examine these possibilities we determined the difference absorption spectra of $\beta$-phenylethylamine and that of a purified bovine plasma monoamine oxidase (type B) in the presence and absence of copper sulfate. Any change in the absorption maxima may be interpreted as a possible interaction between copper and the other components (15).

As shown in figure 2, the addition of $40 \mu \mathrm{mol} / \mathrm{l}$ and $80 \mu \mathrm{mol} / \mathrm{l}$ of copper sulfate increased the net absorption maxima of phenylethylamine at $256 \mathrm{~nm}$ from 0.35 to 0.44 and 0.49 , respectively. At this wave length no absorption of copper chloride was observed. In the visible range, however, between 900 and $700 \mathrm{~nm}$, the absorption maxima of copper sulfate was altered when phenylethylamine was added (data are not shown in this paper). Under similar experimental conditions we observed no interaction between cadmium and phenylethylamine.

The ultraviolet absorption spectra of a purified bovine plasma monoamine oxidase with and without copper sulfate is shown in figure 3 . The maximum absorption of

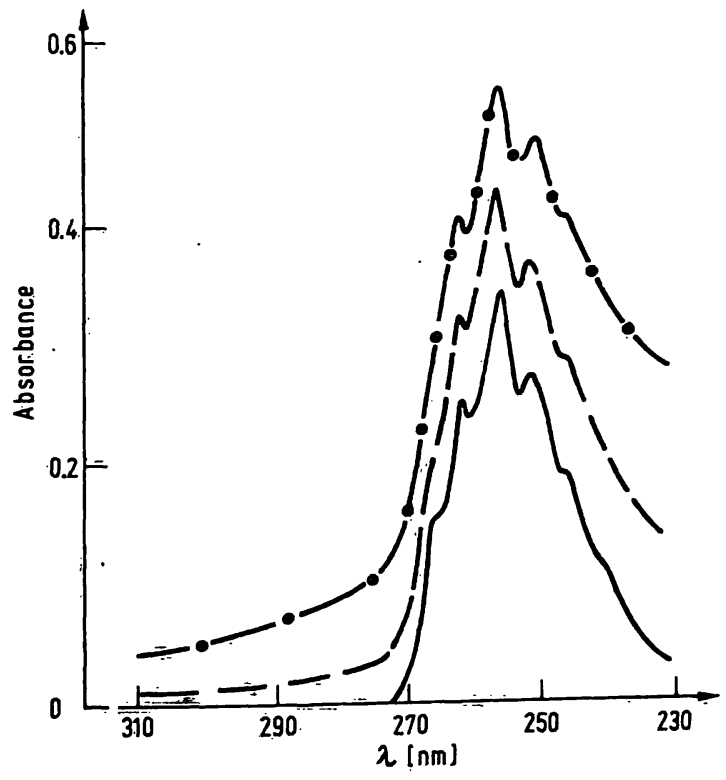

Fig. 2. Difference spectra of $\beta$-phenylethylamine in the presence of copper sulfate: $(-) \beta$-phenylethylamine $2 \mathrm{mmol} / \mathrm{l}$; $(--) \beta$-phenylethylamine $+\mathrm{Cu}^{++} 40 \mathrm{j} \mathrm{mol} / \mathrm{l} ;(\bullet-\bullet)$ $\beta$-phenylethylamine $+\mathrm{Cu}^{++} 80 \mu \mathrm{mol} / \mathrm{l}$.

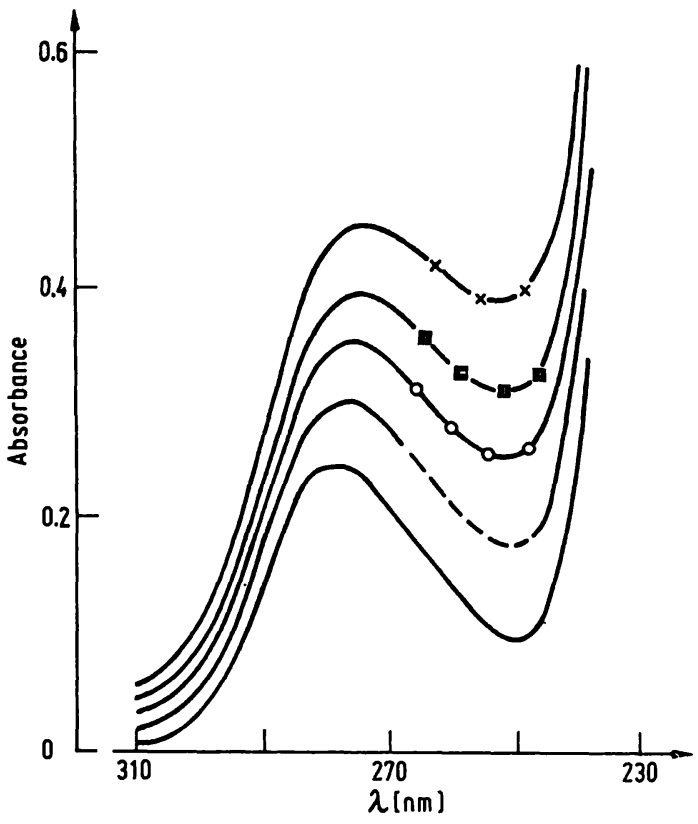

Fig. 3. Difference spectra of plasma monoamine oxidase in the presence of copper sulfate. (-) Enzyme $\left.12.8 \mathrm{U}^{1}\right) / \mathrm{l}$. $(--)$ Enzyme + $\mathrm{Cu}^{++} 20 \mu \mathrm{mol} / \mathrm{l}$. (०-0) Enzyme + $\mathrm{Cu}^{++} 40 \mu \mathrm{mol} / 1$. ( - anzy me $+\mathrm{Cu}^{++} 60 \mu \mathrm{mol} / \mathrm{l}$. $(\mathrm{x}-\mathrm{x})$ Enzyme $+\mathrm{Cu}^{++} 80 \mu \mathrm{mol} / \mathrm{l}$.

plasma monoamine oxidase at $277 \mathrm{~nm}$ was 0.25 . After the addition of $20,40,60$ or $80 \mu \mathrm{mol} / 1$ of $\mathrm{Cu}^{++}$the net absorption maxima were increased to $0.29,0.33,0.36$ and 0.41 , respectively. Under these experimental condition cadmium, in contrast to copper, did not interact with monoamine oxidase in the absorption range between 310 and $250 \mathrm{~nm}$. However, the interaction of cadmium with monoamine oxidase may be detected at wavelengths different from those used in our study.

Although the data in figures 2 and 3 indicate that copper, in contrast to cadmium, interacts with $\beta$-phenylethylamine and plasma monoamine oxidase in the ultraviolet range between 310 and $250 \mathrm{~nm}$, this is certainly not the only reason for the observed inhibitory potency of copper towards the crude mitochondrial enzyme from brain and liver. Moreover, since copper is a redox active transient element, it is reasonable to expect that other mechanisms besides those indicated in figures 2 and 3 may also be involved.

Table 1 shows the $\mathrm{I}_{50}$ s for $\mathrm{Cd}^{++}$and $\mathrm{Cu}^{++}$in the deamination of 5-hydroxytryptamine and phenylentylamine by monoamine oxidase in the brain and liver. The average $\mathrm{I}_{50}$ for cadmium is $100 \mu \mathrm{mol} / \mathrm{l}$ while that of $\mathrm{Cu}^{++}$is $13 \mu \mathrm{mol} / 1$. Although our data indicate that $\mathrm{Cd}^{++}$and $\mathrm{Cu}^{++}$inhibit the monoamine oxidase in vitro, it is certainly of little clinical importance unless it can be confirmed in vivo. Lal et al. (16) have shown that chronic

\footnotetext{
1) 1 Unit enzyme will oxidize $1 \mu \mathrm{mol}$ benzylamine to benzaldehyde per min at $25^{\circ} \mathrm{C}$ and $\mathrm{pH} 7.4$.
} 
treatment (four to six weeks) of rats with $3.75 \mathrm{mg}$ copper sulfate per $\mathrm{kg}$ inhibit the liver monoamine oxidase up to $25 \%$. On the other hand, it is generally known that animals which are exposed to cadmium or copper respond by synthesizing specific cytoplasmic metal-binding proteins (metallothioneins) which are thought to be involved in intracellular detoxification of these heavy metals (17). Taking these together it can then be speculated that if the metal-binding proteins are saturated in an in vivo situation (e.g. during chronic exposure), free unbound cadmium or copper ions may inhibit the monoamine oxidase by $50 \%$ at 11.24 or $0.83 \mu \mathrm{g} / \mathrm{g}$ tissue, respectively (table 1 ). If this were true, it may then be expected that contamination of man with cadmium or copper which are non-specific inhibitors of both types of monoamine oxidase might interfere with the selective monoamine oxidase inhibitor drugs which are currently used in therapy. Moreover, since hepatolenticular degeneration (Wilson's disease) is usually associated
Tab. 1. The $I_{50}$ values for cadmium chloride and copper sulfate in the deamination of 5-hydroxytryptamine and $\beta$ phenylethylamine by mitochondrial preparations from rat brain and liver. Data are expressed as metal concentration in $\mu \mathrm{mol} / 1$ or $\mu \mathrm{g} / \mathrm{g}$ tissue.

\begin{tabular}{|c|c|c|c|c|}
\hline & \multicolumn{2}{|c|}{ Cadmium } & \multicolumn{2}{|l|}{ Copper } \\
\hline & $\begin{array}{l}\text { 5-hy- } \\
\text { droxy- } \\
\text { trypt- } \\
\text { amine }\end{array}$ & 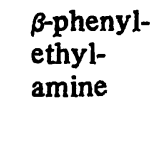 & $\begin{array}{l}\text { 5-hy- } \\
\text { droxy- } \\
\text { trypt- } \\
\text { amine }\end{array}$ & $\begin{array}{l}\beta \text {-phenyl- } \\
\text { ethyl- } \\
\text { amine }\end{array}$ \\
\hline $\begin{array}{l}\text { Brain } \\
\text { Liver }\end{array}$ & $\begin{array}{r}120 \\
80\end{array}$ & $\begin{array}{r}120 \\
80\end{array}$ & $\begin{array}{r}18 \\
9\end{array}$ & $\begin{array}{l}15 \\
10\end{array}$ \\
\hline Av. $I_{50}$ & \multicolumn{2}{|r|}{100} & \multicolumn{2}{|r|}{13} \\
\hline$\mu \mathrm{g}$ Metal per $\mathrm{g}$ & \multicolumn{2}{|c|}{11.24} & \multicolumn{2}{|r|}{0.83} \\
\hline
\end{tabular}

with the deposition of high concentrations of copper in various tissues, it might be of interest to know whether the monoamine oxidase is also inhibited in these patients.

\section{References}

1. Johnston, J. P., (1968), Biochem. Pharmacol. 17, 12851297.

2. Yand, H. Y. T. \& Neff, N. H., (1974), J. Pharmacol. Exp. Ther. 189, 733-740.

3. Jain, M., (1977), Life Sci. 20, 1925-1934.

4. Blaschko, H., (1963), The Enzymes 8, 337.

5. Erwin V. G. \& Hellerman, L., (1967), J. Biol. Chem. 242, 4230-4238.

6. Gomes, B., Naguwa, G., Kloepfer, H. G. \& Yasunobu, K. T., (1969), Arch. Biochem. Biophys. 132, 28-32.

7. Veryovkina I. V., Abdel-Salem, M. M. \& Gorkin, V. Z., (1972), Biochim. Biophys. Acta, 258, 56-70.

8. Passow, H., Rothstein, A. \& Clarkson, T. W., (1969), Pharmacol. Rev. 13, 185-224.

9. Friberg, L., Piscator M. \& Nordberg, G. F., (1971), Cadmium in the Environment. CRC Press, Cleveland, Ohio .
10. Honecker, H., Christ, W., Müller-Oerlinghausen, B. \& Coper H., (1976), J. Clin. Chem. Clin. Biochem. 14, 453-458.

11. Lowry, O. H., Rosebrough, N. J., Farr, A. L. \& Randall, R. J., (1951), J. Biol. Chem. 193, 265-275.

12. Webb, J. L., (1966), Enzymes and Metabolic Inhibitors, Vol. II, Academic Press, New York, p. 635.

13. Revis, H. \& Horton, C, (1978), Toxicol. Appl. Pharmacol. 43, 439-448.

14. Houslay, M. D. \& Tipton, K. F., (1973), Biochem. J. $135,173-186$.

15. Schläfer, H. L. \& Gliemann, G., (1967), Einführung in die Ligandenfeld theorie, Akademische Verlagsgesellschaft, Frankfurt/M.

16. Lal, S., Papesche, R., Ducan, I. S. \& Sourkes, T. L., (1974), Toxicol. Appl. Pharmacol. 28, 395-405.

17. Webb, M., (1975), Biochem. Soc. Trans. 3, 633-634.

Priv. Doz. Dr. S. Magour

Gesellschaft f. Strahlen- u. Umweltforschung Abt. für Toxikologie D-8042 Neuherberg 